\title{
Assessment of the Influence of Rainfall and River Discharge on Sediment Yield in the Upper Tana Catchment in Kenya
}

Imelda N Njogu ${ }^{1 *}$ and Johnson U Kitheka ${ }^{1}$

${ }^{1}$ School of Water Resources Science and Technology, South Eastern Kenya University, Kitui, Kenya

\begin{abstract}
Sediment yield in the Upper Tana Basin in Kenya has implications on the sustainability of Hydro-Electric Power (HEP) dams and water resources development projects. Therefore, a study was undertaken in the basin to establish the extent to which rainfall and river discharges influence the sediment yield in the catchment. The study was based on hydrological data obtained from the Water Resources Management Authority (WARMA) and Kenya Meteorological Department (KMD). The river discharge data was obtained from three RGS Maragua (4BE01), Gura (4AD01) and Tana Sagana (4BC02) and rainfall data was obtained from Sagana Fish Farm and Nyeri Ministry of Works for the of period 1960-2013. The study also applied the Soil Water Assessment Tool (SWAT) Model to determine the extent to which the model can be used to simulate streamflow and sediment yield in the basin. The results of the study showed that there is a significant variability in streamflow and sediment yield in the Upper Tana Basin. In the period between 1960 and 2015, the mean total annual river discharge of Tana Sagana was $128 \mathrm{~m} 3 \mathrm{~s}-1$, and the maximum and minimum river discharges were $29.94 \mathrm{~m} 3 \mathrm{~s}-1$ and $3.15 \mathrm{~m} 3 \mathrm{~s}-1$, respectively. There was an indication of increasing trend in rainfall and subsequently sediment yield in the basin, which may be attributed to alteration of land use and climatic change. The results showed that SWAT model was quite good in simulating the variability of river discharge. The analysis revealed a poor relationship between sediment yield and rainfall. However, the relationship between rainfall and stream flow was strong with $r$ value of 0.9 which is significant at $p=0.05$. Relationship between simulated and observed river discharge had a R2 of 0.442 , $r$ of 0.665 and NSE of -89.43 . The relationship between simulated and observed sediment yield had a R2 of $0.733, r$ of 0.86 and NSE of 0.69 . The results of this study showed that SWAT model can be used to predict sediment yield in the Upper Tana catchment. The model had good performance when daily rainfall, stream flow and sediment yield data were used. Thus, the model can be used to establish the relationship between rainfall, discharge, and sediment yield in a highly human-impacted tropical catchment area. The study puts also forward various recommendations on land and water resources management in the basin.
\end{abstract}

Keywords: SWAT model; Upper tana; Sediment yield; Rainfall; Discharge

\section{Introduction}

Sediment yield in the Upper Tana Basin in Kenya is influenced by many factors among them landuse, vegetation cover, river discharge and rainfall variability [1]. The influences of rainfall and river discharge are particularly important but these are usually complicated by changes in land use and vegetation cover, both seasonally and inter-annually. As a result, the amount of sediment delivered by the river to the hydroelectric power dams located downstream is highly variable. While the influence of land use and vegetation cover change has received a lot of attention in past studies, this cannot be said to be so in case of the influence of rainfall and river discharge variability. In this regard, the assessment of the relationship between river discharge and rainfall and sediment yield is important since it is these two variables that shows significant variability as a result of climate change and whose future trends will have major implications on the dams located in the Upper Dam basin. There is still gap in our understanding of the factors influencing the observed sediment yield in the Upper Tana Basin. In particular, the extent to which rainfall variability and hence climate change influences sediment yields in the basin has not been fully established, as is true in many other similar tropical river basins in Africa. This has been attributed to lack of data. Therefore, to fill the above gaps, we carried out an analysis of the relationship between rainfall, river discharge and sediment yield in some of the key streams draining the Upper Tana Basin in Kenya. This study compliments other studies on sediments yield in the Tana Basin [2-8].

Previous studies carried out on sediment yield in the upper Tana basin have not addressed the relationship between rainfall and discharge and sediment yield. Maingi, et al. [7] examined the hydrologic impacts following construction of dams along the Tana River and Dunne, et al. [3] came up with an approach for estimating the sedimentation in the Upper Tana catchment. Mango, et al. [1] used a calibrated model to explore the potential impacts of continued land use and future climate change in the upper Tana catchment. Dunne T [9] study noted that land use was the main factor that influenced sediment yield. Archer D [10] study in Nairobi region concluded that the sedimentation rates in the reservoirs was high in areas with rainfall amounts ranging between 1000 and $1600 \mathrm{~mm}$ and runoff ranging between 350 and 700 $\mathrm{mm}$. Due to geographical differences, land use, climatic and socioeconomic differences, Archer D [10] generalization for Nairobi region further to the south cannot be applied to the Upper Tana catchment. This study on the Upper Tana catchment is important since it provides information on measures that can be used to mitigate the effects of landuse change in specific areas of the basin which are considered to be the main sources of sediments in the Tana river [11]. By providing an analysis on sediment yield in the basin, the study can contribute in the

*Corresponding author: Imelda N Njogu, School of Water Resources Science and Technology, South Eastern Kenya University, Kitui, Kenya; Tel: +254-714645694, +254-702781796; Email: imeldan@seku.ac.ke

Received January 17, 2016; Accepted January 31, 2017; Published February 07, 2017

Citation: Njogu IN, Kitheka JU (2017) Assessment of the Influence of Rainfall and River Discharge on Sediment Yield in the Upper Tana Catchment in Kenya. Hydrol Current Res 8: 263. doi: 10.4172/2157-7587.1000263

Copyright: ( 2017 Njogu IN, et al. This is an open-access article distributed unde the terms of the Creative Commons Attribution License, which permits unrestricted use, distribution, and reproduction in any medium, provided the original author and source are credited. 
Citation: Njogu IN, Kitheka JU (2017) Assessment of the Influence of Rainfall and River Discharge on Sediment Yield in the Upper Tana Catchment in Kenya. Hydrol Current Res 8: 263. doi: 10.4172/2157-7587.1000263

sustainable management of the Upper Tana Basin and the dams that have been constructed downstream e.g Masinga, Kamburu, Gitaru, Kiambere and the planned Grand Falls dam [8].

\section{Description of the upper Tana basin}

The Upper Tana catchment in Central Kenya, is the main catchment area for the Tana river-the largest river in Kenya (Figure 1). The subbasin covers a surface area of about $12,500 \mathrm{~km}^{2}$ with elevation ranging from 400 to $5,199 \mathrm{~m}$ above sea level. The main rivers in the catchment are Sagana, Thiba, Maragua, Mathioya, Chania, Nyamindi, Chania, Rupingazi, Ena, Tunga and Gura [12]. Five major reservoirs are found in the lower reaches of the sub-basin (Figure 2), namely Kindaruma (completed in 1968), Kamburu, Gitaru, Masinga and Kiambere. These HEP reservoirs combined provide approximately three quarters of electricity in Kenya. Recent studies have shown that they have modified the flow of the Tana river, particularly in downstream reaches of the river up to the Tana Delta [8]. The Upper Tana catchment experiences two rainy seasons every year as a result of the migration of the InterTropical Convergence Zone (ITCZ). The long rain season lasts from March to June, and the short rains from September to December. There is a great variance in the rainfall patterns in Central Kenya highlands. The average annual rainfall ranges between $400 \mathrm{~mm}$ and $2300 \mathrm{~mm}$ [13]. The basin is one of the main water sources of the Tana River basin-the largest and most important river system in Kenya covering basin area of $5,950 \mathrm{~km}^{2}$. The Tana river basin covering $17 \%$ of the total land area in Kenya contributes to $27 \%$ of the total mean discharge in Kenya.

The Upper Tana sub-basin vegetation consists of (i) the forests in the Aberdares conservation area, (ii) the middle zones consisting of farming areas and (iii) the lower drier grazing zone. In the conservation area, vegetation is determined by rainfall distribution and temperature. The forest vegetation in the Aberdares is divided into four categories, namely: the wet evergreen forests; dry evergreen forests; Juniperus podocarpus/Olive forests; and low altitude shrubs. The 10 most common species of trees in the three forest reserves of the Aberdares Conservation Area are Nuxia congesta, Juniperus procera, Olea europaea, Podocarpus latifolius, and Neboutonia macrocalyx $[14,15]$.

The land use in the Upper Tana catchment can be divided into three main classes, namely (i) natural vegetation (forest, grassland, and wetlands), (ii) rain-fed and irrigated agriculture (tea, coffee, maize and cereals) and (iii) Rangeland. The catchment also includes different agro-ecological zones, which corresponds to the different land use types [16]. The population in the Upper Tana catchment is approximately 3.1 million people. The largest urban centres are: Thika, Sagana, Karatina, Murang'a and Nyeri. The population density which is as high as 300 people $/ \mathrm{km}^{2}$ declines with elevation partly due to decreasing rainfall and soil fertility [17]. Most of the people in the basin rely heavily on farming as well as the associated agro-industries which are sources of employment opportunities. The main crops grown include coffee, tea, potatoes, pyrethrum, maize, rice, and bananas.

The soils in the sub-basin are dominated by the humic nitisols which have formed as result of the volcanic deposits on the high-altitude zones. The Nitisol soils are however highly vulnerable to erosion where soil conservation measures are not applied [18]. The other soil types in the catchment include vertisols, cambisols, andosols ferralsols and leptisols. The geology of the area (Figure 3) is characterized by the volcanic rocks of the Cainozoic era, and metamorphic rocks of the Mozambique belt [13]. Mt. Kenya, an extinct volcano formed between 100-4000 million years ago is located in the west of the catchment and is a source of most of the rivers in the Tana basin [19].

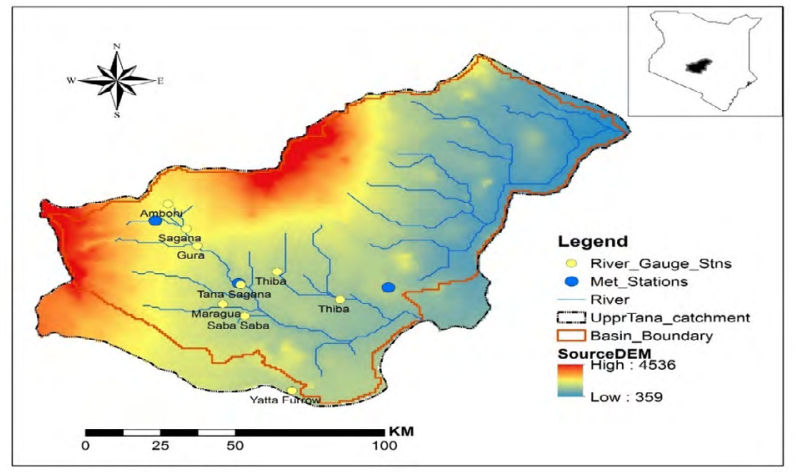

Figure 1: location of the River Gauging Stations (RGS) and rainfall stations in the Upper Tana Basin.

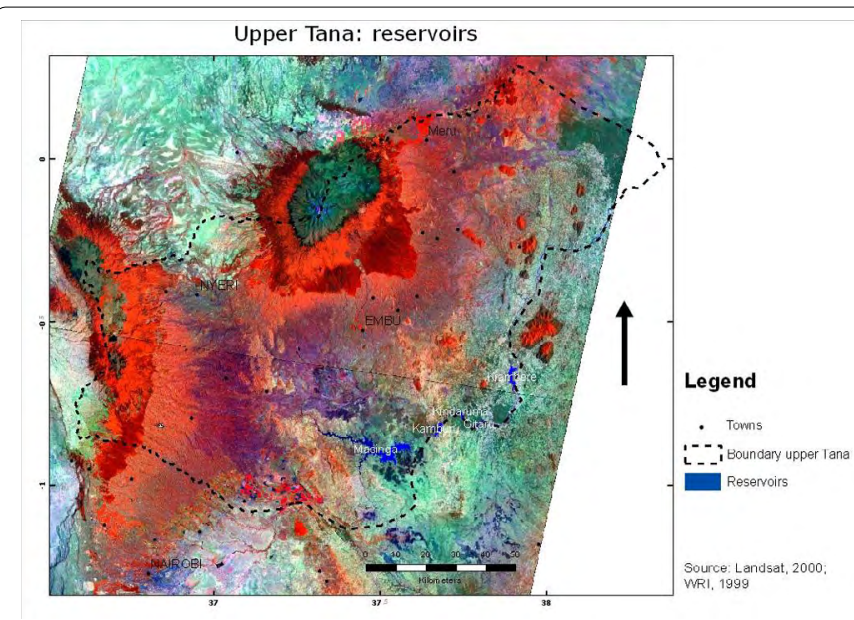

Figure 2: Reservoirs in the Upper Tana catchment.

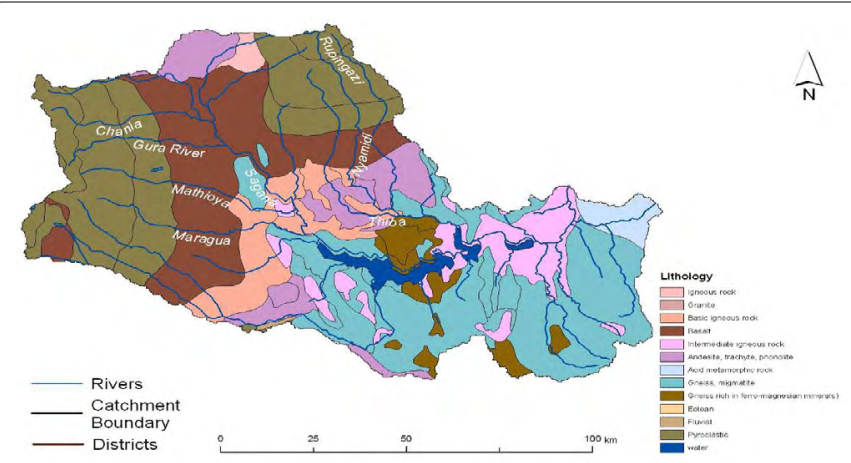

Figure 3: The geology and drainage patterns in the Upper Tana catchment [12].

\section{Methodology}

\section{Streamflow data}

Secondary data on the rainfall, river discharge and sediment yield were obtained from the Kenya's Water Resources Management Authority (WRMA) at Embu. River discharge data were obtained from 8 River Gauging stations (RGS), namely Amboni (4AB05), Sagana (4AC03), Gura (4AD01), Tana Sagana (4BC02), Maragua (4BE01), Thiba 1 (4DD02), Saba Saba (4BF02) and Thiba 2 (4DA10) (Figure 1). 
Citation: Njogu IN, Kitheka JU (2017) Assessment of the Influence of Rainfall and River Discharge on Sediment Yield in the Upper Tana Catchment in Kenya. Hydrol Current Res 8: 263. doi: 10.4172/2157-7587.1000263

Page 3 of 9

\section{Rainfall data}

The rainfall data was obtained from Sagana Fish Farm and Nyeri Ministry of Works Stations that had more consistent records without gaps. Other stations which data was provided by the WARMA included Kiritiri Chiefs Camp (Embu), Sagana State Lodge, Nyeri Met Station, and Meru Forest Station.

\section{Sediment data}

There is a huge gap in terms of availability of sediment data in the Upper Tana basin. Sediment yield data were therefore not available in most of the River Gauging Stations with the exception of the Sagana River Gauging station where continuous data was available for the period 1957-1980. Theother sediment yield data for this station were obtained from WRMA for the following RGS- Tana Sagana (4AC03), Gura (4AD01), Maragua (4BE01) and Sagana- Grandfalls. The SaganaGrandfalls station had continous data for the period 1957 to 1980. The data on the total suspended sediment concentrations (TSSC) was only available for the period between 2010 and 2011 for Maragua (RGS 4BE01), Mathioya (RGS 4BDNEW), Saba Saba (RGS 4BF01) and Sagana (RGS 4BE10).

\section{Data processing and analysis}

The data obtained for this study was subjected to time-series analysis to show the trends in rainfall, sediment yield and river discharge in the period between 1957 and 1990 and in some instances, up to 2015.The flow duration curves and mass curves were plotted for rainfall and river discharge data for Sagana fish farm and Gura RGS, respectively. This was done in order to check the accuracy of the SWAT model and also for detecting shifts in rainfall and river discharges in the basin.

\section{The soil water assessment tool (SWAT) model}

TheSoil Water Assessment Tool(SWAT) Model was used to simulate flow rates of the Sagana river which is the main branch emanating from the Upper Tana Basin. The SWAT model has been used in other parts of the world [20-23]. The model dealt with two parameters in the input stage rainfall and discharge of the river. The output of the model was plotted in Excel to show the relationship between measured data and simulated model data on rainfall, sediment yield and discharge. Various quantitative methods used included the measures of central tendency (mean, range), regression analysis, correlation and coefficient of determination and Nash Sutcliffe Efficiency (NSE). The SWAT model was built using the Arc-Map interface (i.e Arc SWAT) which provided the suitable means to enter data into the SWAT code. The SWAT Model deals with soil and water parameters, with primary data inputs being the Digital Elevation Model (DEM), land use and soils shape files. Modelling allowed quantification of soil erosion processes at non-gauged areas and during periods when measurements were absent [24]. The Model was calibrated using data for the period between 1981 and 2010. Model validation was done using datasets from the Gura river gauging station (1980-1985). For modeling purposes, the Upper Tana watershed was partitioned into a number of sub-basins. Input information for each sub-basin was then grouped or organized into the following categories: climate and hydrologic response units (HRUs). The first step in creating a SWAT model involved the delineation of the sub-watersheds in the Upper Tana basin for which each of them is treated as individual units. The sub-basins were further divided into hydrologic response units (HRUs) which had homogenous land use practices, soil type and management practices. The Nash-Sutcliffe efficiency (NSE) was used to as a normalized statistic to determine the relative magnitude of the residual variance compared to the measured data variance [25]. NSE indicates how well the plot of observed versus simulated data fits the 1:1 line. Servat, et al. [26] noted that NSE provides the best objective function for reflecting the overall fit of a hydrograph. The NSE equation used is presented in equation 1 :

$$
N S E=1-\left[\sum_{i=1}^{n} \frac{\left(y_{i}^{\text {obs }}-y_{i}^{\text {sim }}\right)^{2}}{\left(y_{i}^{\text {obs }}-y_{i}^{\text {mean }}\right)^{2}}\right]
$$

Where,

$\mathrm{Y}_{\mathrm{i}}^{\text {obs }}-\mathrm{i}^{\text {th }}=\mathrm{observation}$ for the constituent being evaluated

$\mathrm{Y}_{\mathrm{i}}^{\text {sim }}-\mathrm{i}^{\text {th }}=$ simulated value for the constituent being evaluated

$\mathrm{Y}^{\text {mean }}=$ mean of the observed data for the constituent being evaluated

$\mathrm{N}=$ total number of observations.

The Nash Sutcliffe Efficiency ranges from $-\infty$ to +1 , where the acceptable levels of performance are the values greater or equal to 0.0 to 1. If the NSE number is less than 0.0 it indicates that the mean observed value is a better predictor than the simulated value, which indicates unacceptable performance of the model.

The long-term calibration was validated with inflow data from the Gura River Gauging station that was found to have the least data gaps. A monthly dataset was available from 1981-2010.The erosion rates and sediment yields were calibrated using the model values that were compared with the model predictions to calibrate the soil erosion and sediment routing parameters of the model. The mode fine-tuning was done using the data available from the various RGS and meteorological stations to improve the accuracy of the model parameters and the output. The long-term calibration spurned a 30 -year period in which the basin has changed considerably in terms of land use and in terms of infrastructure roads, small-scale hydraulic works, and diversions.

\section{Statistical data analysis}

Multiple regression models presented in equations 2 and 3 were used in this study, respectively.

$$
\begin{aligned}
& \mathrm{Y}=\mathrm{ax}_{1}^{2}+\mathrm{bx}_{2}+\mathrm{c} \\
& \mathrm{Y}=\mathrm{a}+\mathrm{bX}+\mathrm{e}
\end{aligned}
$$

In above equations,

$\mathrm{Y}=$ Sediment Yield (tons. month ${ }^{-1}$ )

$\mathrm{a}$ and $\mathrm{b}=$ the coefficients value of $\mathrm{X}$ variables

$\mathrm{X}_{1}=$ River discharge $\left(\mathrm{m}^{3}\right.$ month $\left.^{-1}\right)$

$\mathrm{X}_{2}=$ Rainfall (mm.month $\left.{ }^{-1}\right)$

$\mathrm{c}=$ Constant.

The regression equation was deemed to be significant when the $\mathrm{p}$-value is less or equal to 0.05 . The correlation analysis was based on the Pearson's correlation coefficient ( $r$ ) that was used to describe the degree of collinearity between simulated and measured data according to equation 4 .

$$
r=\frac{n=\left(\sum x y\right)-\left(\sum x\right)\left(\sum y\right)}{\sqrt{\left[n \sum x^{2}-\left(\sum x\right)^{2}\right]\left[n \sum y^{2}-\left(\sum y\right)^{2}\right]}}
$$

In above equation,

$r=$ Correlation coefficient 
$y=$ Dependent variable (e.g. Sediment Yield)

$x=$ Independent variable (e.g. River Discharge)

$n=$ Total number of values.

The coefficient of determination $R^{2}$ describing the proportion of the variance in measured data explained by the model was computed using equation 5 [27].

$\mathrm{R}^{2}=\sqrt{ } \mathrm{r}(5)$

Where $R^{2}=$ coefficient of determination

$r=$ Pearson's correlation coefficient

$R^{2}$ ranges from 0 to 1 , with higher values indicating less error variance, and typically, values greater than 0.5 are considered acceptable $[28,29]$. Analysis of Variance (ANOVA) was used to determine whether there exist significant differences between two or more variables at a selected probability level. One-way analysis of variance was used in testing hypothesis at $95 \%$ confidence level. The null hypothesis was rejected when the critical $\mathrm{F}>\mathrm{F}$ and when the $\mathrm{p}$-value $(\mathrm{x})>0.05$.

\section{Results}

\section{Seasonal and inter-annual variability of river discharges}

The stream flow in the rivers draining the Upper Tana Basin showed significant seasonal and inter-annual variabilities. The high stream flows are experienced during the two rainy seasons, namely long rain season (March, April, and May) and short rain season (October, November, and December). The low stream flows are experienced during the dry seasons (June, July, August, September and January, February). The streamflows also show significant inter-annual variabilities. The maximum river discharges for Amboni (RGS 4AB05), Maragua (RGS 4BE01), Gura (RGS 4AD01) and Tana Sagana (RGS 4BC02) were 4.84 $\mathrm{m}^{3} \mathrm{~s}^{-1}, 33.25 \mathrm{~m}^{3} \mathrm{~s}^{-1}, 29.94 \mathrm{~m}^{3} \mathrm{~s}^{-1}$ and $59.26 \mathrm{~m}^{3} \mathrm{~s}^{-1}$, respectively. The mean river discharges for Amboni (RGS 4AB05), Maragua (RGS 4BE01), Gura (RGS 4AD01) and Tana Sagana (RGS 4BC02) were $1.5 \mathrm{~m}^{3} \mathrm{~s}^{-1}, 14.3$ $\mathrm{m}^{3} \mathrm{~s}^{-1}, 19.7 \mathrm{~m}^{3} \mathrm{~s}^{-1}$ and $21.2 \mathrm{~m}^{3} \mathrm{~s}^{-1}$, respectively. Tana Sagana had relatively higher discharge since it represents the main tributary of the Tana draining from the northwest Upper Tana Basin. The flow duration curves of the rivers showed that the high magnitude flows $>80 \mathrm{~m}^{3} \mathrm{~s}^{-1}$ are experienced in $<10 \%$ of the time, while river discharges $<10 \mathrm{~m}^{3} \mathrm{~s}^{-1}$ occur in $80 \%$ of the time (Figure 4 ).

\section{Seasonal and inter-annual variability of sediment yield}

The data on the total suspended sediment concentrations (TSSC) for four RGS for the period between 2010 and 2011 showed existence of significant seasonal and inter-annual variability of TSSC. Maragua river (RGS 4BE01) had a minimum, maximum and mean TSSC of 3 $\mathrm{mgl}^{-1}, 0.517 \mathrm{gl}^{-1}$ and $0.065 \mathrm{gl}^{-1}$, respectively. Mathioya (4BDNEW) had a minimum, maximum and mean of $3 \mathrm{mgl}^{-1}, 0.258 \mathrm{gl}^{-1}$ and $0.043 \mathrm{gl}^{-1}$ respectively. Saba Saba (4BF01) had a minimum, maximum and mean of $0.010 \mathrm{gl}^{-1}, 1.433 \mathrm{gl}^{-1}$ and $0.243 \mathrm{gl}^{-1}$ respectively. Sagana (4BE10) had a minimum, maximum and mean of $0.03 \mathrm{gl}^{-1}, 0.50 \mathrm{gl}^{-1}$ and $0.057 \mathrm{gl}^{-1}$, respectively. The TSSC ranged from 0.03 to $0.50 \mathrm{gl}^{-1}$ in Sagana river in the period between 2010-2011. The highest TSSC were recorded in the Sagana river which is the main branch of the Tana draining from the northwest Upper Tana Basin. As with TSSC, Sediment yield in the Upper Tana Basin showed both seasonal and inter-annual variabilities. The data for the period between 1955 and 1995, showed that the variability of sediment yield is related to the variability of rainfall and subsequently river discharges (Figure 5).
The computation of sediment yield provided a maximum yield of 39,050 ton.yr $\mathrm{r}^{-1}$ in 1961 and $>50,000$ ton.yr ${ }^{-1}$ in 2015 . The 1961 sediment yield data are much lower than the 2015 yield, probably pointing to an increase in sediment production in the basin. There is thus an indication of increased sediment yield in the basin. The sediment yields for Maragua, Mathioya, Saba Saba and Sagana were 1,365,603 ton.yr ${ }^{1}, 798,365$ ton. $\mathrm{yr}^{-1}, 216,210$ ton. $\mathrm{yr}^{-1}$ and $2,782,547$ ton. $\mathrm{yr}^{-1}$, respectively. Previous studies in the basin by Dunne, et al. [3] reported sediment yields ranging from 883,000 ton. $\mathrm{yr}^{-1}$ and 2,302,000 ton. $\mathrm{yr}^{-1}$, respectively. From the results of sediment yield from different sub-basins, it seems that Maragua and Mathioya are the main sources of sediment in the Upper Tana basin.

\section{Seasonal and inter-annual variations of rainfall}

The rainfall trend shows normal year-to year variability although there is an indication of declining rainfall trend. As with rainfall, the river discharges show normal year to year variations that are related to the variability in rainfall. The sediment yields also showed significant inter-annual variations. Rainfall in the Upper Tana Basin based on data obtained at Nyeri Public Works station and Sagana Fish Farm station showed significant inter-annual variations with an indication of declining trend in the period between 1980 and 2010 (Figure 5). There is also an indication of an increase in the degree of variability indicating an increase in the frequency and magnitude of extreme rainfall events. It is possible that the declining trend in rainfall observed in the Upper Tana Basin is a result of climate variability or land use change. It is however difficult at this stage to determine exactly what is the main driver. While rainfall shows a declining trend, the degree of variability seems to have increased after 1990.

The relationship between rainfall and streamflow in the basin was significant with correlation coefficient $r$ of 0.99 and coefficient of determination $R^{2}$ of 0.98 . This indicates that variations in rainfall explains $98 \%$ of the variations in river discharges in the Upper Tana Basin. This would also indicate rapid basin response with limited baseflow contributions to streamflow. This could be a result of land degradation occasioned by increased destruction of catchment areas for agriculture and settlements (Figure 6).

\section{Land-use change in the upper Tana basin}

There has been significant change in land-use in the Upper Tana Basin when one compares the situation during the pre-colonial and post-colonial period. Major significant changes in land-use begun in 1920s following introductions of agriculture in Central Kenya Highlands by European settlers [30]. In the last 100 years, there has

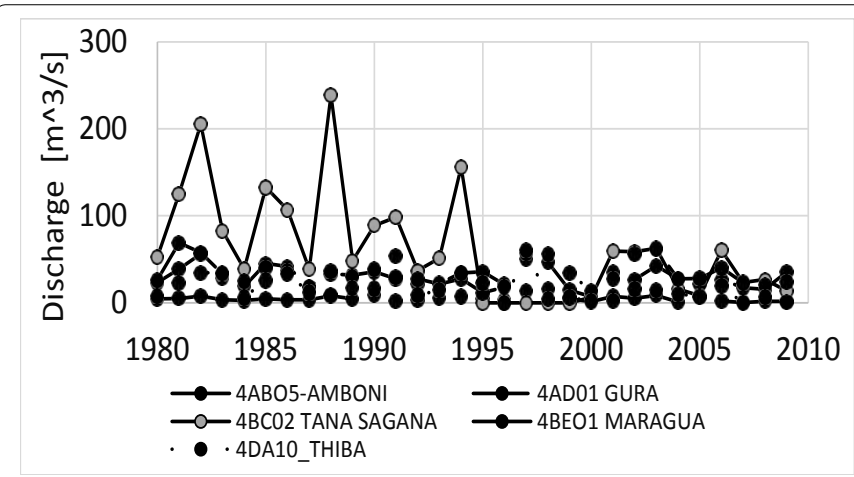

Figure 4: Variability of river discharge at Amboni and Gura River Gauging Stations (RGS) in the Upper Tana Basin in the period between 1980 and 2009. 


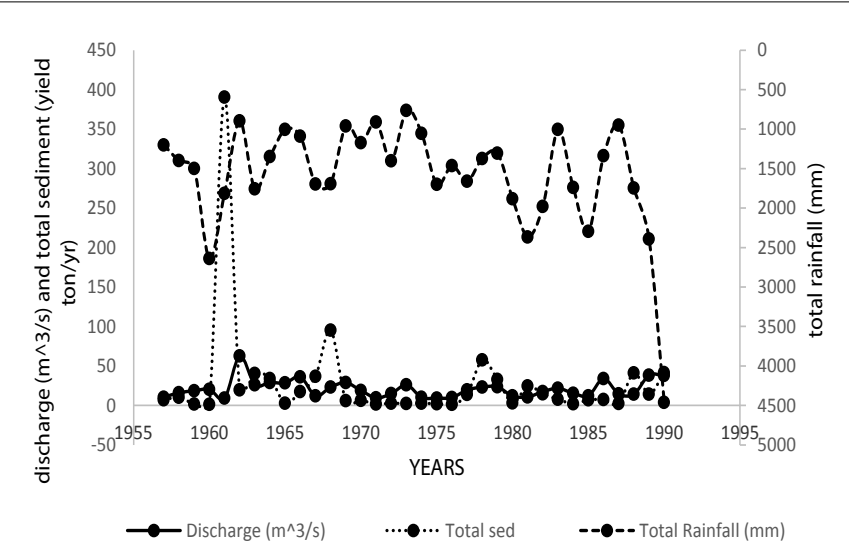

Figure 5: Inter-annual variations of sediment yield, rainfall, and river discharge in the Upper Tana in the period between 1957 and 1990.

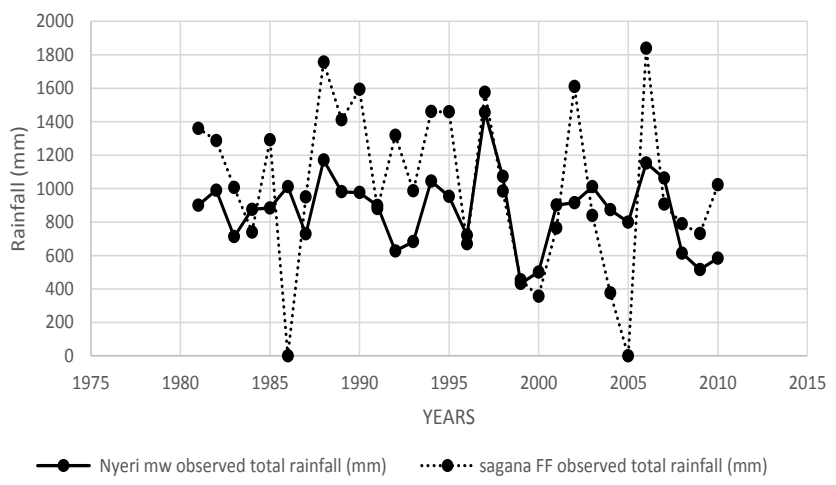

Figure 6: Inter-annual variations of total annual rainfall at Nyeri and Sagana stations in the period between 1981 and 2010.

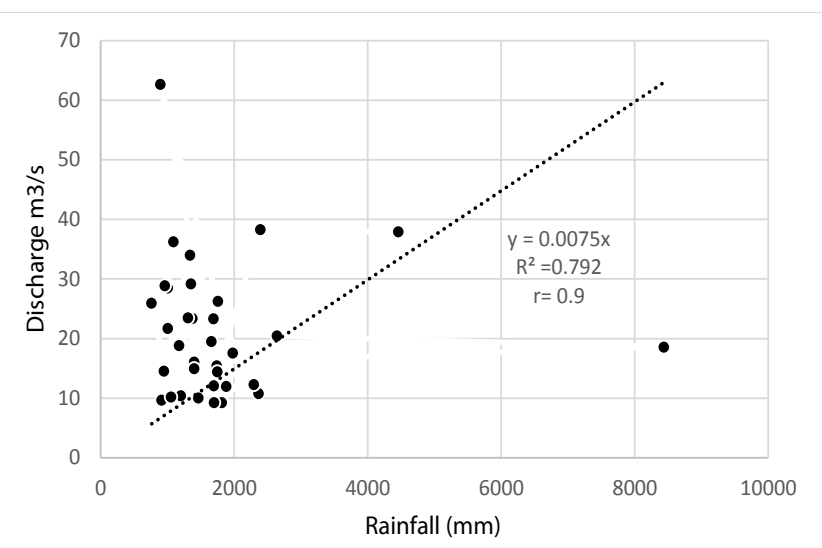

Figure 7: The relationship between river discharge and rainfall at Sagana River Gauging Station (RGS) in the Upper Tana Basin in the period 1981-2010.

been major changes in land use and vegetation cover in the basin. The analysis of satellite images and aerial photographs showed that the forest cover has reduced by more than $50 \%$. Agriculture and settlements have increased by more than $100 \%$. The population in the Upper Tana Basin has increased from $<250,000$ people in 1969 to $>2$ million people in 2015 [30]. High population density and intensive cropping in the region leave the soils susceptible to soil erosion. Most of the cultivation is done without the application of appropriate soil erosion protection measures and the cultivation on marginal lands having steep slopes or high erodibility have increased (Figure 7).

\section{Simulation of stream flow and sediment yield}

The streamflow in the Upper Tana was modeled using SWAT model using data obtained at Gura River Station for the period between 1980 and 2010. The results of simulation of river discharges are shown in Figure 8. The relationship between simulated and observed river discharge yielded a correlation coefficient $r$ of 0.67 with $R^{2}$ value of 0.44 . The NSE index for the relationship was 89 showing the model simulated $89 \%$ of the streamflows (Figure 9 and 10).

The sediment yields were simulated using data for the period between 1980 and 2010 at Sagana River Gauging station. The comparison between simulated and observed sediment yield showed that the relationship was weak with $\mathrm{r}$ value of 0.02 with $\mathrm{R}^{2}$ value $<0.01$. Thus, the SWAT model did not simulate the measured sediment yield satisfactorily (Figure 11 and 12).

An attempt was made to establish whether there is a significant relationship between rainfall and measured sediment yield at Sagana RGS in the Upper Tana Basin, for the period 1980 and 2010. The results showed a relatively weak relationship with a correlation coefficient $(r)$ of 0.16 and a coefficient of determination $\left(R^{2}\right)$ of 0.026 . These results imply that there is no significant relationship between total annual rainfall and total annual sediment yield in the Upper Tana Basin. This perhaps points to other factors that are playing an important role in determining the annual sediment yield in the basin. It could also be due to problems with the quality of data or due to the fact that actual rainfall was not used to establish the link with the actual sediment yield.

The suspended sediment concentrations in the Upper Tana vary widely with as low as $0.03 \mathrm{gl}^{-1}$ and values greater than $1.40 \mathrm{gl}^{-1}$. Maragua river (RGS 4BE01) had a minimum, maximum and mean of $0.03 \mathrm{gl}^{-1}$, $0.517 \mathrm{gl}^{-1}$ and $0.065 \mathrm{gl}^{-1}$, respectively. Mathioya river (4BDNEW) hada minimum, maximum and mean of $0.03 \mathrm{gl}^{-1}, 0.258 \mathrm{gl}^{-1}$ and $0.043 \mathrm{gl}^{-1}$, respectively. Saba Saba river (4BF01) had a minimum, maximum and mean of $0.010 \mathrm{gl}^{-1}, 1.433 \mathrm{gl}^{-1}$ and $0.243 \mathrm{gl}^{-1}$, respectively. Sagana river (4BE10) had a minimum, maximum and mean of $0.03 \mathrm{gl}^{-1}, 0.500 \mathrm{gl}^{-1}$ and $0,057 \mathrm{gl}^{-1}$, respectively. These river gauging stations Maragua, Mathioya, Saba Saba and Sagana had sediment yields of 1,365,603 ton. $\mathrm{yr}^{-1}, 798,365$ ton. $\mathrm{yr}^{-1}, 216,210$ ton.yr $\mathrm{r}^{-1}$ and 2,782,547 ton. $\mathrm{yr}^{-1}$, respectively.

The results of regression analysis showed that there is no significant relationship between rainfall and river discharge $(p=0.9)$. The same can be said to be true for the relationship between river discharge and sediment concentration, and that between river discharge and sediment yield. In other words, there is no indication that an increase in rainfall will cause a corresponding increase in stream flow. The weak relationship between river discharge and sediment yield and TSSC could be attributed to the time lag between the variables.

\section{Discussion}

\section{Stream flow and rainfall}

The discharge of the main rivers found in the Upper Tana Basin showed an increase in the range of low and high flows, indicative of large variation in stream flow. For instance, in Tana Sagana river, the high flows reached $239 \mathrm{~m}^{3} \mathrm{~s}^{-1}$ while the base flows were of the order 


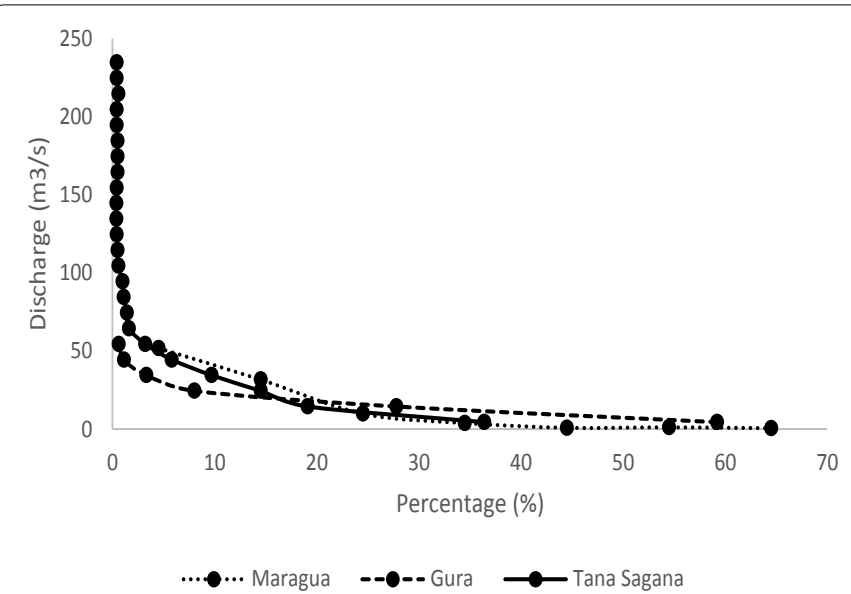

Figure 8: Flow duration curve for Maragua River Gauging Station (RGS) in the Upper Tana Basin based on river discharge data for the period 1981-2010.

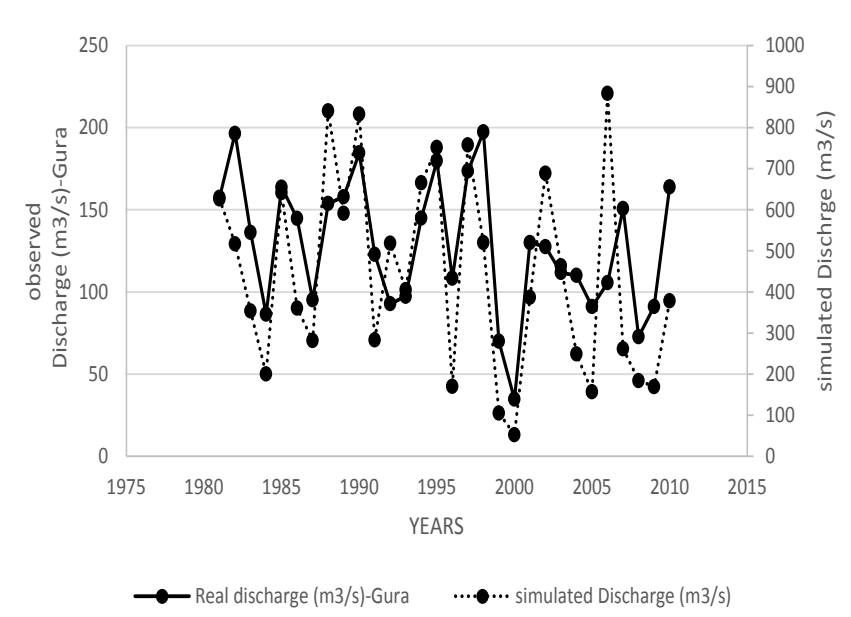

Figure 9: The variations of the simulated and observed total river discharge at Gura River Gauging Station (RGS) in the period 1980-2010.

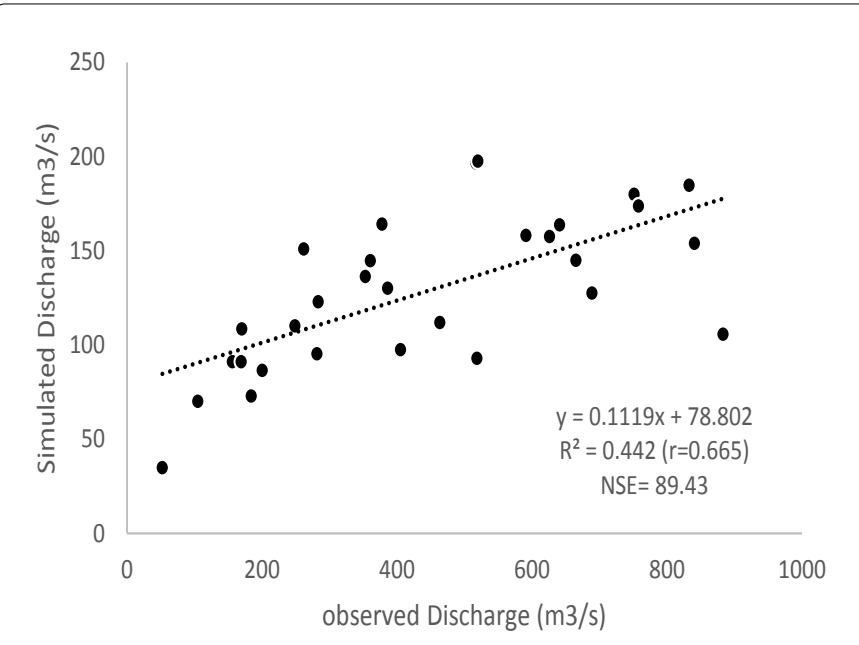

Figure 10: The relationship between the simulated and observed river discharge at Gura River Gauging Station (RGS) in the period between 1981 and 2010.
$0.12 \mathrm{~m}^{3} \mathrm{~s}^{-1}$. There is also an indication of the reduction of stream flow which can be attributed to changes in land-use practices (e.g. increased cultivation, increased settled areas), increased deforestation of the catchment areas and reduced glacial cover on Mt. Kenya as a result of climate change. The variability of rainfall in the basin which has showed great variability could also be a factor in the increased variability of stream flow. However, the decreased flow could be due to increased abstraction of water (for irrigation, domestic and municipal water supply). Some of the rivers in the Upper Tana catchment have been tapped for the supply of water of water to Ndakaini Dam that supplies water to the City of Nairobi. It is expected that the tapping of the high flows $>80 \mathrm{~m}^{3} \mathrm{~s}^{-1}$ under the Northern Collector Tunnel will further cause a reduction in the total stream flow of the Tana Sagana [31].

\section{Sediment yield and rainfall and discharge}

Sediment yield in the Upper Tana Basin is a consequence of poor land-use practices that causes high rates of soil erosion. The period 1960-1961 was characterized by high sediment yield which can be attributed to high rainfall events during the same period. There is an indication of a lag between the occurrence of high rainfall event in 1960 and the corresponding high sediment transport rate in early 1961. However, there is no clear indication of an increase in sediment transport rate since 1960, despite high variabilities that are clearly evident in our data. It is not certain whether reforestation and soil conservation programmes in the basin could explain this scenario.

The rainfall in the Upper Tana Basin exhibits significant spatial variations. The maximum total rainfall at Sagana is $1,839 \mathrm{~mm}$ while at Nyeri it is $1,456.3 \mathrm{~mm}$. The minimum values for Sagana and Nyeri were $357 \mathrm{~mm}$ and $501.3 \mathrm{~mm}$, respectively. The results of simulation of rainfall showed that variabilities are largely due to the difference in the location of the stations. Both Sagana and Nyeri stations showed a negative gradient (-12.49 and -4.93$)$ meaning the amount of rainfall is reducing in the region. This is in agreement with findings of other studies done in the region [8].

\section{Simulation of river discharges and sediment yield in the upper Tana basin}

The results of simulation of river discharges in the Upper Tana are based on the results for Gura river. The results had $(r)$ value of 0.665 , a $R^{2}$ value of 0.442 and NSE of -89.43 . These results show a good relationship between the two datasets, although the $R^{2}$ value is low. This can be explained by the gaps in the available data. The $R^{2}$ value showed a small error in the variance of the two datasets. The NSE of -89.43 shows that the mean observed river discharge for the Gura RGS is a better predictor than the mean simulated value and hence an unacceptable performance of the model. The high values for the Gura RGS were over-predicted by the model while in some instances they were under-predicted. The low river discharge values were generally under-predicted which explains the low efficiency in the simulation.

The results obtained for the observed and simulated sediment yield provided a (r) value of 0.02 , a $R^{2}$ value of 0.0005 and NSE of -0.6. The $r$ and $R^{2}$ are low because of relying on the model data. There was no data to input for the model to run as the available data was provided annually and the model required data in daily form. The NSE clearly shows that the mean observed value is a better predictor than the mean simulated value, this means that this is an unacceptable level of performance for the model to simulate sediment yield, and we would rather rely on the observed data as opposed to simulated data. The high values for the sediment yield were highly over-predicted with the low values being highly under-predicted. 


\section{Factors influencing sediment yield}

The main objective of this study was to determine how rainfall influences sediment yield in the upper Tana catchment. According to the results of SWAT model, the amount of rainfall had a low significance influence on the amount of sediment yield in the Upper Tana catchment (Figure 12), with a $r$ value of -0.25 and $R^{2}$ value of -0.062 . The simulated data on rainfall was used for the plotting because the model produced a good simulation between the observed and simulated data for the Sagana fish culture farm. The results obtained for the relationship between rainfall and sediment yield is quite low on the $r$ and $R^{2}$ which can be attributed to low performance of the model to simulate sediment yield. The data available was in annual form while the model required data in daily format. It would be expected from the graph that an increase in rainfall would result to an increase in the amount of sediment yield but this is not the case in many years. This shows that there are other factors apart from rainfall that influence the amount of sediment yield in the Upper Tana catchment. According to the results provided by the model, the amount of rainfall and sediment yield has no threat to the future of the Masinga dam reservoir. However, land use and the type of soil are the major determinant of the sediment supply to the reservoir. This is in agreement with other studies carried out by Kitheka, et.al. [8], that found a correlation of 0 . 67. Mutiso (1980) found a correlation coefficient $r$ of 0.8 which is much higher than the one reported in this study which is 0.5 . The difference is attributed to the approaches used to determine the relationship between the parameters and the difference in geographical locations. This can also be attributed to the use of different data sets. The multiple regression analysis on the extent to which sediment yield is influenced by stream flow and rainfall variations yielded $r$ value of 0.973 and $R^{2}$ of 0.94 at $95 \%$ confidence level $(p=0.05)$. This shows the combined influences of rainfall and river discharge influence sediment yield. This study established that there is a good relationship between river discharge and sediment yield in the Upper Tana basin. This is expected since increased river discharge is associated with the increased capacity to transport the detached sediments [32].

\section{Variability of sediment yield}

The production of sediments in the Upper Tana Basin is a consequence of soil erosion processes in the sub-basin. Soil erosion is influenced by numerous factors among them rainfall, runoff, landuse, vegetation cover, and soil erodibility. This study has examined the influence of river runoff and rainfall. The extent to which land-use change and soil erodibility influences sediment production in the basin has not been examined in detail due to lack of data. However, we based our arguments on their contributions from the results of other studies.

The computation of sediment yield in the basin was done using the river discharge data and suspended sediment concentrations (TSSC) data for Sagana river. This was based on the mean, maximum and minimum TSSC values of $0.384 \mathrm{gl}^{-1}, 0.032 \mathrm{gl}^{-1}$ and $0.0042 \mathrm{gl}^{-1}$ respectively and the corresponding mean, maximum and minimum river discharges of $20.53 \mathrm{~m}^{3} \mathrm{~s}^{-1}, 62.56 \mathrm{~m}^{3} \mathrm{~s}^{-1}$ and $9.23 \mathrm{~m}^{3} \mathrm{~s}^{-1}$, respectively. These data yielded the mean, maximum and minimum sediment yield of $31,062,960$ ton. $\mathrm{km}^{2} / \mathrm{yr}, 781,777,440$ ton. $\mathrm{km}^{2} / \mathrm{yr}$ and 157,680 ton. $\mathrm{km}^{2} / \mathrm{yr}$ respectively.

The Upper Tana catchment has changed considerably in terms of land use with increased extent of Cultivated areas due to increased population, increased livestock keeping and in terms of infrastructure roads, small-scale hydraulic works, and diversions $[9,33]$. There exists a strong relationship between the land-use and sediment yield in the

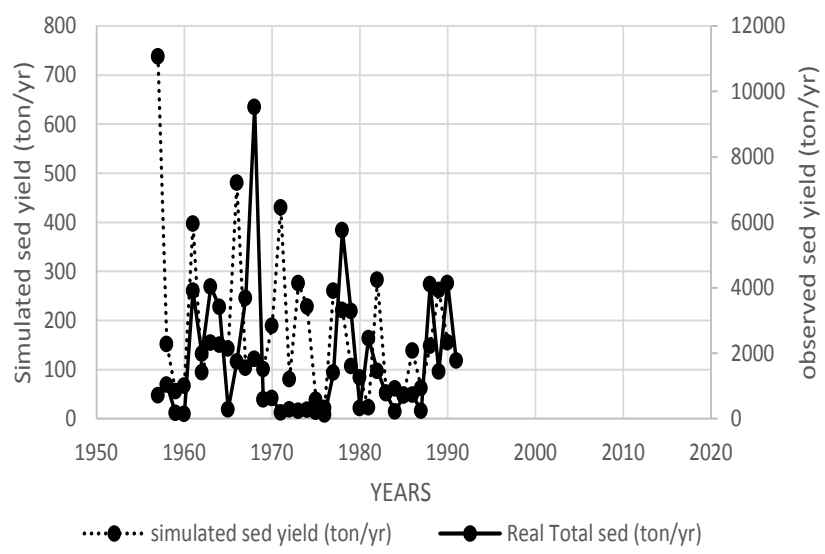

Figure 11: The variations of the simulated and observed total sediment yield for the period of 1981-2010 at Sagana River Gauging Station (RGS).

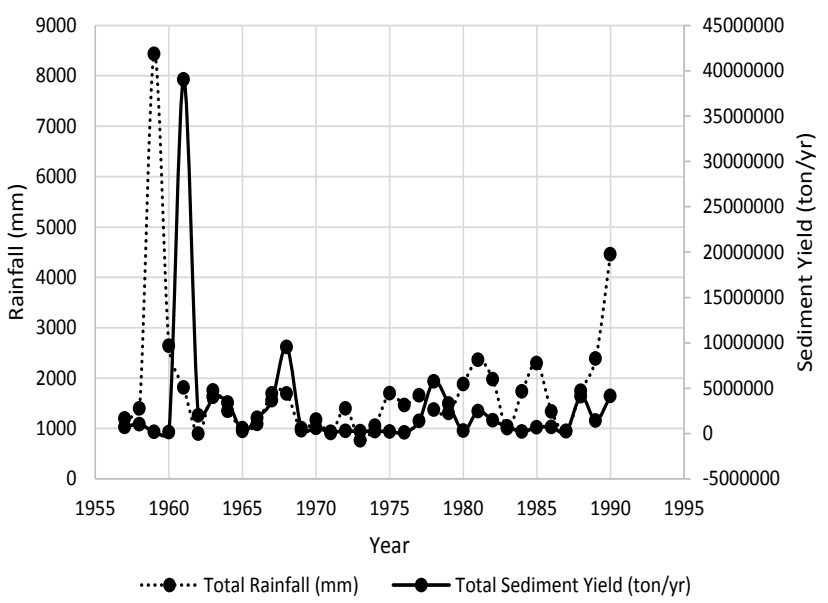

Figure 12: The variations of the observed total rainfall and observed total sediment yield for the period 1955-1995 at Sagana River Gauging Station (RGS).

Upper Tana catchment. The consequence of high sediment yield is the siltation of the Masinga dam reservoir [4,5,7-9]. The primary concern of high sediment discharge in the Masinga reservoir is the loss of storage capacity which affects the economic life of the reservoir. Loss of storage capacity hampers a reservoir's ability to fulfill its main functions which includes; store water, which impacts on other functions, e.g. power generation, irrigation supply, flood control, navigation, and domestic water supply. Due to the nonlinear relationship between water yield and reservoir capacity, even a small loss of reservoir capacity can result in substantial reductions in reservoir yield [34].

\section{Sustainable land-use and protection of reservoirs in the upper Tana basin}

Sustainable land use practices are seen as one of the best approaches of reducing sediment yield in the Upper Tana Basin. This can be done through application of various management practices which have the potential to benefit both upstream as downstream stakeholders. These include strip cropping, gully erosion control [9], and reforestation. There is a need for a comprehensive reforestation programme in the 
Citation: Njogu IN, Kitheka JU (2017) Assessment of the Influence of Rainfall and River Discharge on Sediment Yield in the Upper Tana Catchment in Kenya. Hydrol Current Res 8: 263. doi: 10.4172/2157-7587.1000263

Upper Tana catchment. There is also a need for eco-hydrological studies to establish the relationship and feedbacks between ecological and the hydrological processes [35]. In addition, there is need for comprehensive monitoring of river discharges, rainfall and sediment yield by the WRMA. Data collection programme should be consistent to avoid gaps in hydrological and climatological data [36-41].

\section{References}

1. Mango LM, Melesse AM, McClain ME, Gann D, Setegn SG (2011) Land use and climate change impacts on the hydrology of the upper Mara River Basin, Kenya: results of a modeling study to support better resource management. Hydrology and Earth System Sciences 15: 2245-2258.

2. Kitheka JU, Nthenge P, Obiero M (2003) Dynamics of sediment transport and exchange in the Tana estuary in Kenya. School of Water Resources Science and Technology.

3. Dunne T, Ongweny GS (1976) A new estimate of sedimentation rates on the upper Tana River. The Kenyan Geographer 2: 109-126.

4. Ongwenyi GSO (1978) Erosion and sediment transport in the Upper Tana catchment with special reference to the Thiba basin. Unpublished PhD thesis, University of Nairobi.

5. Ongwenyi GSO (1979) Patterns of sediment production in the Upper Tana basin in Eastern Kenya. In: Hydrology of Areas of Low Precipitation. Proceedings of Canberra Symposium, pp: 447-457.

6. Maingi SM (1991) Sedimentation in Masinga Reservoir. Unpublished MSc Thesis, Appropriate Technology Centre, Kenyatta University, Nairobi.

7. Maingi JK, Marsh SE (2002) Quantifying hydrologic impacts following dam construction along the Tana River, Kenya. Journal of Arid Environments 50: 53-79.

8. Kitheka JU (2014) Assessment of modification of the Tana River runoff due to developments in the Upper Tana Basin. In: The Proceedings of the $2^{\text {nd }}$ Hydrological Society of Kenya (HSK) Workshop: "Hydrology in Water Cooperation and Security for Sustainable Economic Development". SubTheme: Hydrology and Sustainable Development, Nairobi, Kenya, pp: 178-191.

9. Dunne T (1979) Sediment yield and land use in tropical catchments. Journal of hydrology 42: 281-300.

10. Archer D (1996) Suspended sediment yields in the Nairobi area of Kenya and environmental controls. IAHS Publications-Series of Proceedings and ReportsIntern Assoc Hydrological Sciences 236: 37-48.

11. Ongwenyi GS (1983) Development of water resources. In the Kenyan Geographer-special issue on the Proceedings of the Nairobi workshop: Strategies for developing the resources of the semi-arid areas of Kenya, pp. 36-47.

12. Geertsma R, Wilschut L, Kauffman JH (2010) Review for the Green Water Credits Pilot Operations in Kenya. Green Water Credits Report 8 / ISRIC Report 2010/02, ISRIC- World Soil Information, Wageningen.

13. Notter B, MacMillan L, Viviroli D, Weingartner R, Liniger HP (2007) Impacts of environmental change on water resources in the Mt. Kenya region. Journal of Hydrology 343: 266-278.

14. Mutangah JG, Mwangangi O, Mwaura PK, Shem OM, Abiero L, et al. (1992) Kenya Indigenous Forest Conservation Programme.

15. Lamond G (2007) Local knowledge of biodiversity and ecosystem services in smallholder coffee farms in Central Province, Kenya (Doctoral dissertation, Master Thesis, Bangor. School of the Environment and Natural Resources, University of Wales, Bangor).

16. Jaetzold R, Helmut SH (1983) Farm Management Handbook of Kenya: Natural Conditions and Farm Management Information, Central Kenya: (Rift Valley and Central Provinces)/ Ministry of Agriculture, Kenya, pp: 3-29.

17. Vahabi J, Nikkami D (2008) Assessing dominant factors affecting soil erosion using a portable rainfall simulator. International Journal of Sediment Research 23: 376-386.

18. Nachtergaele FO, van Velthuizen $\mathrm{H}$, Verelst L, Batjes $\mathrm{NH}$, Dijkshoorn JA, et al. (2008). Harmonized world soil database (Version 1.0). Food and Agric
Organization of the UN (FAO); International Inst. for Applied Systems Analysis (IIASA); ISRIC-World Soil Information; Inst of Soil Science-Chinese Acad of Sciences (ISS-CAS); EC-Joint Research Centre (JRC).

19. Baker BH (1967) Geology of the Mount Kenya area. Geological Survey of Kenya, pp: 78-79.

20. Tripathi MP, Panda RK, Raghuwanshi NS (2003) Identification and prioritisation of critical sub-watersheds for soil conservation management using the SWAT model. Biosystems Engineering 85: 365-379.

21. Parajuli PB, Mankin KR, Barnes PL (2008) Applicability of targeting vegetative filter strips to abate fecal bacteria and sediment yield using SWAT. Agricultural water management 95: 1189-1200.

22. Levesque E, Anctil F, Van Griensven ANN, Beauchamp N (2008) Evaluation of streamflow simulation by SWAT model for two small watersheds under snowmelt and rainfall. Hydrological sciences journal 53: 961-976.

23. Rostamian R, Jaleh A, Afyuni M, Mousavi SF, Heidarpour M, et al. (2008) Application of a SWAT model for estimating runoff and sediment in two mountainous basins in central Iran. Hydrological Sciences Journal 53: 977-988.

24. Neitsch SL, Arnold JG, Srinivasan R (2002) Pesticides fate and transport predicted by the soil and water assessment tool (SWAT). Final report submitted to Office of Pesticide Programs. Washington, DC: USEPA.

25. Nash JE, Sutcliffe JV (1970) River flow forecasting through conceptual models part I- A discussion of principles. Journal of hydrology 10: 282-290.

26. Servat E, Dezetter A (1991) Selection of calibration objective functions in the context of rainfall-runoff modelling in a Sudanese savannah area. Hydrological Sciences Journal 36: 307-330.

27. Legates DR, McCabe GJ (1999) Evaluating the use of "goodness-of-fit" measures in hydrologic and hydroclimatic model validation. Water resources research 35: 233-241.

28. Santhi C, Arnold JG, Williams JR, Dugas WA, Srinivasan R, et al. (2001) Validation of the SWAT model on a large water river basin with point and nonpoint sources. JAWRA Journal of the American Water Resources Association, 37: 1169-1188.

29. Van Liew MW, Arnold JG, Garbrecht JD (2003) Hydrologic simulation on agricultural watersheds: Choosing between two models. Transactions of the ASAE, 46: 1539-1551.

30. Jacobs J, Angerer J, Vitale J, Srinivasen R, Kaitho R, et al. (2004) Exploring the potential impact of reforestation on the hydrology of the upper Tana River catchment and the Masinga Dam, Kenya. Impact Assessment Group, Cent. For Natural Resource Information Technol., Texas A and M Univ., College Station, pp: 11-13.

31. Runo KS (2015) Evaluation of geological conditions along the proposed northern collector tunnel using electrical resistivity tomography method in Gatanga, Kenya, Doctoral dissertation, University of Nairobi.

32. Kitheka JU, Mavuti KM, Nthenge P, Obiero M (2014) The dynamics of the turbidity maximum zone in a tropical Sabaki estuary in Kenya.

33. McCully $P$ (1996) Rivers no more: the environmental effects of dams, Zed Books, pp: 29-64.

34. Annandale GW (1987) Reservoir sedimentation. Elsevier 99-116.

35. Zalewski M (2002) Eco-hydrology-The use of cological and hydrological processes for sustainable management of water resources. Hydrological Sciences Journal 47: 823-832.

36. Palmieri A, Shah F, Dinar A(2001) Economics of reservoir sedimentation and sustainable management of dams. Journal of Environmental Management 61: 149-163.

37. Mati BM, Morgan RP, Gichuki FN, Quinton JN, Brewer TR, et al. (2000) Assessment of erosion hazard with the USLE and GIS: A case study of the Upper EwasoNg'iro North basin of Kenya. International Journal of Applied Earth Observation and Geoinformation 2: 78-86.

38. Kitheka JU, Obiero M, Nthenge P (2005) River discharge, sediment transport and exchange in the Tana Estuary, Kenya. Estuarine, Coastal and Shelf Science 63: 455-468. 
Citation: Njogu IN, Kitheka JU (2017) Assessment of the Influence of Rainfall and River Discharge on Sediment Yield in the Upper Tana Catchment in Kenya. Hydrol Current Res 8: 263. doi: 10.4172/2157-7587.1000263

Page 9 of 9

39. Kitheka JU, Mavuti KM (2016) Tana Delta and Sabaki Estuaries of Kenya: Freshwater and Sediment Input, Upstream Threats and Management Challenges. In Estuaries: A Lifeline of Ecosystem Services in the Western Indian Ocean. Springer International Publishing, pp: 89-109.

40. Baker TJ, Miller SN (2013) Using the Soil and Water Assessment Tool
(SWAT) to assess land use impact on water resources in an East African watershed. Journal of Hydrology 486: 100-111.

41. Fao I (2002) WFP (2002) Reducing poverty and hunger: the critical role of financing for food, agriculture and rural development, pp: 18-22. 